\title{
Investigation of soil properties and pesticide intensity in crop lands at Tangail region of Bangladesh
}

\author{
T.N. Shila ${ }^{1}$, M.S. Islam ${ }^{1 *(D)}$, M.M.M. Hoque ${ }^{1}$, M.H. Kabir ${ }^{1}$, M.R. Jamil ${ }^{1}$ and U. Kumar ${ }^{2}$ \\ Received 23 July 2021, Revised 9 November 2021, Accepted 20 December 2021, Published online 31 December 2021
}

\section{A B S T R A C T}

The study was conducted to investigate the soil properties and pesticide intensity in rice, banana and brinjal growing agricultural land of Delduar and Sakhipur upazila of Tangail district during July 2019 to June 2020. Forty five soil samples were collected from different crop land at the study area and analyzed in the Soil Resource Development Institute to determine the soil properties as $\mathrm{pH}$, total organic matter $(\mathrm{OM})$, total nitrogen $(\mathrm{N})$, available phosphorus (P), available sulfur (S), available zinc $(\mathrm{Zn})$, exchangeable potassium (K), exchangeable magnesium ( $\mathrm{Mg}$ ) and exchangeable calcium (Ca). However, pesticide used intensity was also evaluated through questionnaire survey with farmers and stakeholders in the study area. Results showed that $\mathrm{pH}, \mathrm{OM}$, available $\mathrm{N}$, exchangeable $\mathrm{Ca}$ and exchangeable $\mathrm{Mg}$ content were significantly higher in rice growing land than banana and brinjal. On the other hand, available $\mathrm{P}$, exchangeable $\mathrm{K}$ and available $\mathrm{Zn}$ content were substantially higher in brinjal growing land than rice and banana. The OM showed significant positive correlation with soil $\mathrm{pH}$, available $\mathrm{N}$, available $\mathrm{S}$, exchangeable $\mathrm{Mg}$ and exchangeable $\mathrm{Ca}$ ( $\mathrm{r}=0.37,0.99,0.31,0.59$ and 0.63 , respectively), indicated rice growing land built up these soil properties through increasing soil OM. The available $P$ showed significant and positive correlation with $\mathrm{K}$ and $\mathrm{Zn}(\mathrm{r}=0.55$ and 0.74 , respectively), but negative correlation with exchangeable $\mathrm{Mg}$ and exchangeable $\mathrm{Ca}(\mathrm{r}=-0.53$ and -0.32 , respectively). The exchangeable $\mathrm{K}$ showed significant and positive correlation with available $\mathrm{Zn}(\mathrm{r}=0.45)$ but negative correlation with exchangeable $\mathrm{Mg}(\mathrm{r}=-0.37)$. The $\mathrm{Mg}$ showed significant negative correlation with available $\mathrm{Zn}(\mathrm{r}=-0.45)$ but positive correlation with exchangeable $\mathrm{Ca}(\mathrm{r}=0.87)$. Results also revealed that pesticide used intensity was higher in brinjal followed by banana and minimum in rice crop. Study suggests that farmers require up-to-date information on soil nutrient status so that they may use the proper utilization of fertilizers and avoid using excessive amounts of fertilizers and pesticides in their crop land.

Keywords: Soil fertility, Land use, Pesticide intensity, Organic matter

${ }^{1}$ Department of Environmental Science and Resource Management, Mawlana Bhashani Science and Technology University, Tangail-1902, Bangladesh

${ }^{2}$ Soil Resource Development Institute, Regional Office, Tangail-1900, Bangladesh

*Corresponding author's email: islammstazu@yahoo.com (M.S. Islam)

Cite this article as: Shila, T.N., Islam, M.S., Hoque, M.M.M., Kabir, M.H., Jamil, M.R. and Kumar, U. 2021. Investigation of soil properties and pesticide intensity in crop lands at Tangail region of Bangladesh. Int. J. Agril. Res. Innov. Tech. 11(2): 85-94. https://doi.org/10.3329/ijarit.v11i2.57260

\section{Introduction}

In Bangladesh, agriculture acts as a driving force of the national economy. In most of the developing countries, agricultural income plays a key role in the overall economic performance of the country, not only in terms of its contribution to gross domestic product, but also as a major source of foreign exchange earnings, providing employment to a large segment of the population (BBS, 2018). To meet the growing demand of foods, three different cropping seasons are practiced in Bangladesh (Islam et al., 2020a). Modern agriculture is wholly dependent on the chemicals in the form of pesticides with aim to suppress plant and animal pests to protect agricultural and industrial products. Pesticides are bioactive, toxic substances and they directly or indirectly influence soil productivity and agroecosystem quality. Owing to the massive damage caused by pests to agricultural fields and crops, production often declines below the level of subsistence for farmers, which can eventually have adverse effects on the national economy (Imfeld and Vuilleumier, 2012). 
About $70 \%$ pesticides are used only on rice fields (PAB, 2000) and most of the people of this country are directly or indirectly related to agriculture. Farmers rely on chemical pesticides including toxic chemicals compare to traditional and IPM method (Parveen and Nakagoshi, 2001). Thus, use of pesticides is increased over the years in this country (Meisner, 2004). Pesticide is so indispensable in agricultural production, about one-third of the agricultural products are produced by using pesticides (Liu et al., 2002). In a developing country like Bangladesh, more than 90\% of farmers used pesticide without knowing its actual requirements, they used pesticide unnecessarily, indiscriminately and excessively at high concentration, and more frequent due to their ignorance and unconsciousness (Akhter et al., 2016). In this process pesticide misuses become more and more serious, which has resulted in heavy environmental pollution and health risk of humans (Prasad et al., 2014). Many pesticides are not easily degradable, they persist in soil, leach to groundwater and runoff can carry pesticides into aquatic environment and contaminate the wide environment. Depending on their chemical properties they can enter the organism, bioaccumulate in food chains and consequently influence human health. Sprayed pesticides give effects other than on their target species, including effects on non-target sites such as air, water and the soil (Conway, 1984).

Soil fertility is an important factor, which determines the growth of plant. Soil fertility is determined by the presence or absence of chemical properties. The availability of chemical properties (micronutrients) is particularly sensitive to changes in soil environment. The factors that affect the contents of such micronutrients are organic matter, soil $\mathrm{pH}$, lime content, sand, silt, and clay contents revealed from different research experiments (Nazif et al., 2006). Soil fertility status is a complex and dynamics system that is the important quality indicator of soil. Pesticide application in most cases significantly affects the microbial properties of soil and the corresponding changes have been observed in soil-fertility as well (Cycon and Piotrowska-Seget, 2007). Thus, the study was attempted to know the soil fertility status of rice, banana and brinjal growing land, and to investigate the pesticide use intensity in rice, banana and brinjal crops.

\section{Materials and Methods}

\section{Study area}

The study area is located in Delduar and Sakhipur upazila of Tangail district, the central part of Bangladesh. The Delduar upazila is located at $24^{\circ} \mathrm{O} 5^{\prime}$ to $24^{\circ} 14^{\prime} \mathrm{N}$ latitudes and $89^{\circ} 50^{\prime}$ to $89^{\circ} 59^{\prime} \mathrm{E}$ longitudes, the Sakhipur upazila is located at $24^{\circ} 11^{\prime}$ to $24^{\circ} 26^{\prime} \mathrm{N}$ latitudes and $90^{\circ} 04^{\prime}$ to $90^{\circ} 18^{\prime} \mathrm{E}$ longitudes (Fig. 1). Main crops of the two upazila are rice, wheat, mustard, potato, onion, ginger, garlic, pulse and vegetables. The study was conducted during July 2019 to June 2020.

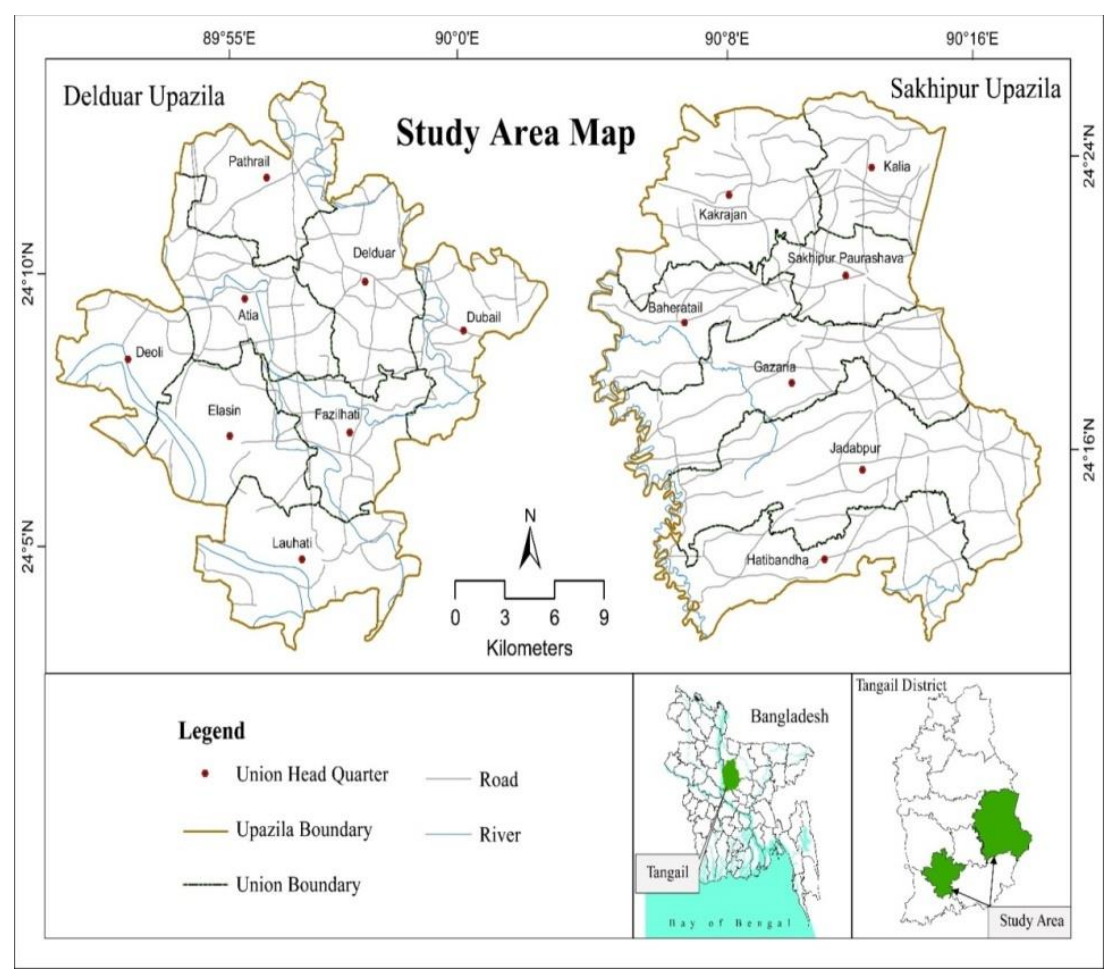

Fig. 1. Map showing the study area of Delduar and Sakhipur upazila of Tangail district. 


\section{Sample collection}

Total 45 soil samples were collected from different crops land in the study area to know their nutritional status for crop production. Among them, 15 samples were collected from rice, 15 from banana and 15 from brinjal cultivated land. The samples were scraped from the top to bottom (o to $10 \mathrm{~cm}$ ) with the help of an auger. Then $250 \mathrm{~g}$ soil was taken to have a representative sample. All samples were placed in sealed polythene bags and labeled with date of collection, location and code number. From the collected samples, the gravels, pebbles, plant roots, leaves etc. were dried in air for 15 days by spreading on a clean piece of polythene bag then samples were mixed well, ground to pass through a 2-mm plastic sieve, and preserved in polythene bags for laboratory analysis. The primary information about the use of pesticide was collected through questionnaire survey techniques, which was conducted on three groups of respondents as i) farmers, ii) agrochemical dealers, and iii) Sub-assistant Agricultural Officer (SAAO) in the study area.

\section{Sample analysis}

The soil samples were dried in room temperature and carefully transported to the laboratory of Soil Resource Development Institute (SRDI), Tangail for analysis of soil $\mathrm{pH}$, total organic matter (OM), total nitrogen $(\mathrm{N})$, available phosphorus (P), available zinc (Zn), available sulfur (S), exchangeable potassium (K), exchangeable calcium ( $\mathrm{Ca}$ ) and exchangeable magnesium (Mg). The soil $\mathrm{pH}$ was determined by digital $\mathrm{pH}$ meter. The OM of soil sample was determined by Walkley and Black's wet oxidation method (Huq and Alam, 2005). Total $\mathrm{N}$ of soil samples were determined by semi-micro Kjeldhal method (Sattar and Rahman, 1987). The available P of soil was determined by using the Olsen method
(Sattar and Rahman, 1987). The available Zn was determined by DTPA method (Roberts et al., 1971). The available $S$ in soil was determined by Calcium Chloride Extraction Method (Sattar and Rahman, 1987). The exchangeable $\mathrm{K}$ in soil was determined by ammonium acetate extraction method (Sattar and Rahman, 1987). The exchangeable $\mathrm{Ca}$ and $\mathrm{Mg}$ of soil samples were determined by EDTA (Ethylenediamene Tetra Acetic Acid) titration method (Huq and Alam, 2005).

\section{Statistical analysis}

After receiving the soil parameters laboratory test results from SRDI, data were compiled, tabulated and analyzed through Microsoft Office Excel software and SPSS (version 20.0). Pearson's correlation analysis was done to illustrate the interrelationships between the soil properties.

\section{Results and Discussion}

\section{Soil pH}

Rice growing land showed significantly highest $\mathrm{pH}$ (5.85) which was similar with brinjal growing land (5.79), whereas banana growing land showed the lowest pH (5.53) (Fig. 2). Neutral pH (6.6 to 7.3) is the optimum for all the agricultural crop production (Ahmed et al., 2018). Soil pH of rice and brinjal growing land were slightly acidic whereas it was strongly acidic in banana growing land (Table 1). The result is well corroborated with Kumar et al. (2019), they found that rice cultivated medium high and medium low land had slightly acidic, whereas vegetables cultivated high land was strongly acidic in Tangail region of Bangladesh. In Kalihati upazila of Tangail, soil $\mathrm{pH}$ ranged from 4.85 to 6.74 (Islam et al., 2020b). Excessive acidity is detrimental to soil health, which increases soil toxicity and fixed available phosphorous (Hart et al., 2013).

Table 1. Soil fertility status of different crops growing lands in the study area.

\begin{tabular}{|c|c|c|c|c|c|c|c|c|c|}
\hline Crops land & $\mathrm{pH}$ & $\begin{array}{l}\mathrm{OM} \\
(\%)\end{array}$ & $\begin{array}{l}\mathrm{N} \\
(\%)\end{array}$ & $\begin{array}{c}\mathrm{P} \\
\left(\mu \mathrm{g} \mathrm{g}^{-1}\right)\end{array}$ & $\begin{array}{c}\mathrm{Zn} \\
\left(\mu \mathrm{g} \mathrm{g}^{-1}\right)\end{array}$ & $\begin{array}{c}S \\
\left(\mu \mathrm{g} \mathrm{g}^{-1}\right)\end{array}$ & $\begin{array}{c}\mathrm{K} \\
\text { (meq } 100 \mathrm{~g}^{-1}\end{array}$ & $\begin{array}{c}\mathrm{Ca} \\
\text { neq } 100 \mathrm{~g}^{-1}\end{array}$ & $\begin{array}{c}\mathrm{Mg} \\
\left(\mathrm{meq} 100 \mathrm{~g}^{-1}\right)\end{array}$ \\
\hline Rice & $5.85 \mathrm{~A}$ & $2.16 \mathrm{~A}$ & $0.10 \mathrm{~A}$ & $10.23 \mathrm{C}$ & $0.84 \mathrm{~B}$ & $35.53 \mathrm{~A}$ & $0.14 \mathrm{C}$ & $9.04 \mathrm{~A}$ & $2.04 \mathrm{~A}$ \\
\hline Status & SlA & Medium & Low & Low & Low & High & Low & Very high & Very high \\
\hline Banana & $5.53 \mathrm{~B}$ & $1.64 \mathrm{~B}$ & $0.08 \mathrm{~B}$ & 68.12 B & $3.79 \mathrm{~B}$ & $30.23 \mathrm{~A}$ & $0.29 \mathrm{~B}$ & $4.88 \mathrm{~B}$ & $0.77 \mathrm{~B}$ \\
\hline Status & StA & Low & Very low & Very high & Very high & High & Optimum & Optimum & Medium \\
\hline Brinjal & $5.79 \mathrm{~A}$ & $1.83 \mathrm{~B}$ & $0.09 \mathrm{~B}$ & $127.21 \mathrm{~A}$ & $4.97 \mathrm{~A}$ & $32.78 \mathrm{~A}$ & $0.39 \mathrm{~A}$ & $6.09 \mathrm{~B}$ & $0.95 \mathrm{~B}$ \\
\hline Status & SlA & Medium & Very low & Very high & Very high & High & High & High & Medium \\
\hline Optimum & $5.60-7 \cdot 30$ & $1.71-3.40$ & $0.27-0.36$ & $22.51-30.00$ & $1.35-1.80$ & $22.51-30.00$ & $0.27-0.36$ & $4.51-6.00$ & $1.12-1.50$ \\
\hline$\% \mathrm{CV}$ & 5.88 & 19.84 & 19.17 & 45.53 & 54.41 & 30.76 & 42.55 & 35.56 & 31.59 \\
\hline LSD & 0.2519 & 0.2793 & 0.0134 & 23.337 & 1.3025 & $7 \cdot 5577$ & 0.0872 & 1.7753 & 0.2962 \\
\hline
\end{tabular}

Note: $S l A=$ Slightly Acidic, $S t A=$ Strongly Acidic. 


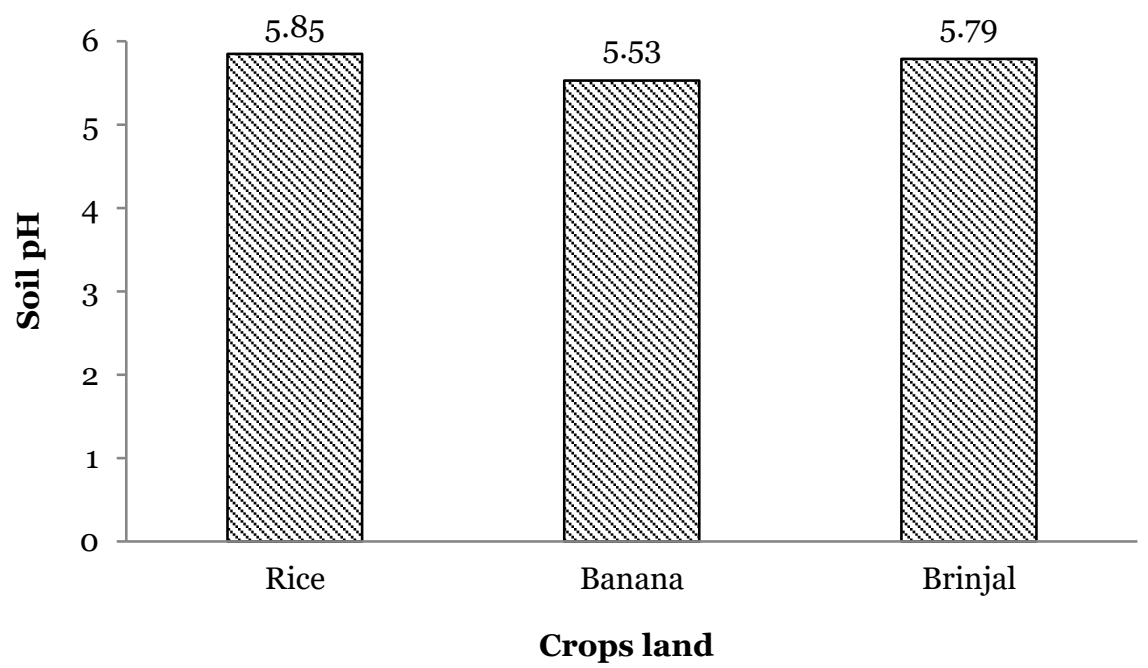

Fig. 2. The $\mathrm{pH}$ of different crops growing lands in the study area.

\section{Organic matter (OM)}

Rice growing land showed significantly highest OM (2.16\%) whereas banana growing land showed lowest (1.64\%), which was similar with brinjal growing land (1.83\%) (Fig. 3). About 3.4\% $\mathrm{OM}$ is suitable for almost all agricultural crop production (Ahmed et al., 2018). The OM status of rice and brinjal growing land were medium, whereas it was low in banana growing land (Table 1). The result reveled that OM status depleted in all crop growing lands. It might be due to quick decomposition of $\mathrm{OM}$ in wet land rice cultivation and high oxidation rate of high land soil. Rice is cultivated in medium high land to very low land but banana and brinjal are cultivated in high land only. The decomposition rate of $\mathrm{OM}$ is higher in high land than other land types. That is why high land showed low OM status than others land. The OM ranged from 1.86 to $3.65 \%$ with an average of $2.30 \%$ i.e., medium status in nature (Islam et al., 2020b). The OM was lower in high land $(2.11 \%)$ than medium high land $(2.31 \%)$ and medium low land (2.33\%) (Kumar et al., 2019).

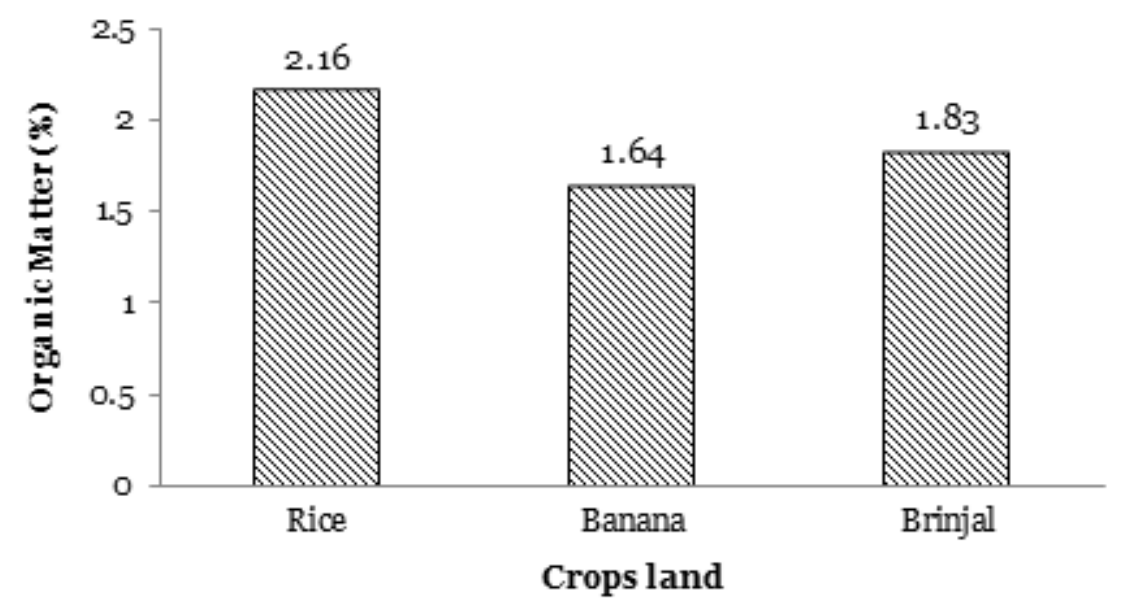

Fig. 3. The organic matter status of different crops growing lands in the study area.

\section{Total nitrogen ( $N$ )}

Rice growing land showed significantly highest total $\mathrm{N}(0.10 \%)$ in soil, whereas banana growing land showed lowest (0.08\%), which was similar with brinjal growing land (o.09\%) (Fig. 4). More than $0.27 \%$ is the optimum level of total $\mathrm{N}$ for all the agricultural crop production (Ahmed et al., 2018). Total N of banana and brinjal growing land were very low whereas it was low in rice growing land (Table 1). It might be due to denitrification, leaching and immobilization of nitrogen from the soil. According to Islam et al. (2020b), total $\mathrm{N}$ in soil ranged from 0.09 to $0.18 \%$ with a mean of $0.12 \%$ which was below the optimum level. Total $\mathrm{N}$ was lower in high land $(0.11 \%)$ than medium high $(0.12 \%)$ and medium low land (0.12\%) in Tangail district (Kumar et al., 2019). 


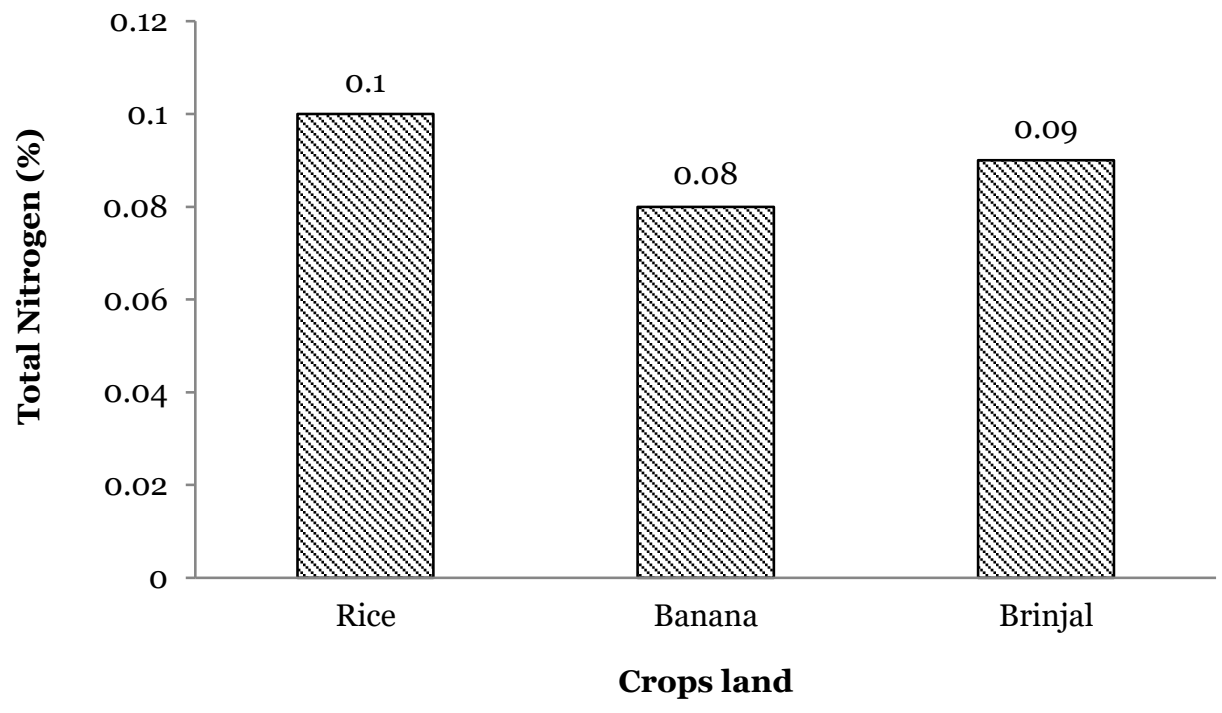

Fig. 4. Total nitrogen status of different crops growing lands in the study area.

\section{Available phosphorus (P)}

Brinjal and Banana growing land showed significantly highest available $\mathrm{P}\left(127.21 \mu \mathrm{g} \mathrm{g}^{-1}\right.$ and $\left.68.12 \mu \mathrm{g} \mathrm{g}^{-1}\right)$, whereas rice growing land showed lowest (10.23 $\mu \mathrm{g} \mathrm{g-1)}$ available $\mathrm{P}$ (Fig. 5). The optimum level of available $\mathrm{P}$ is 22.51 to $30.00 \mu \mathrm{g}$ $\mathrm{g}^{-1}$ for all the agricultural crop production (Ahmed et al., 2018). Available P of banana and brinjal growing land were very high, whereas it was low in rice growing land (Table 1). Islam et al. (2020b) recorded mean available $\mathrm{P}$ was 3.50 $\mu \mathrm{g} \mathrm{g}^{-1}$, which indicated very low status of nutrient in Kalihati upazila of Tangail. Available P was higher in high land (11.06 $\left.\mu \mathrm{g} \mathrm{g}^{-1}\right)$ than medium

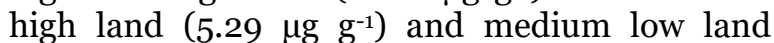
(7.78 $\left.\mu \mathrm{g} \mathrm{g}^{-1}\right)$ in Tangail (Kumar et al., 2019).

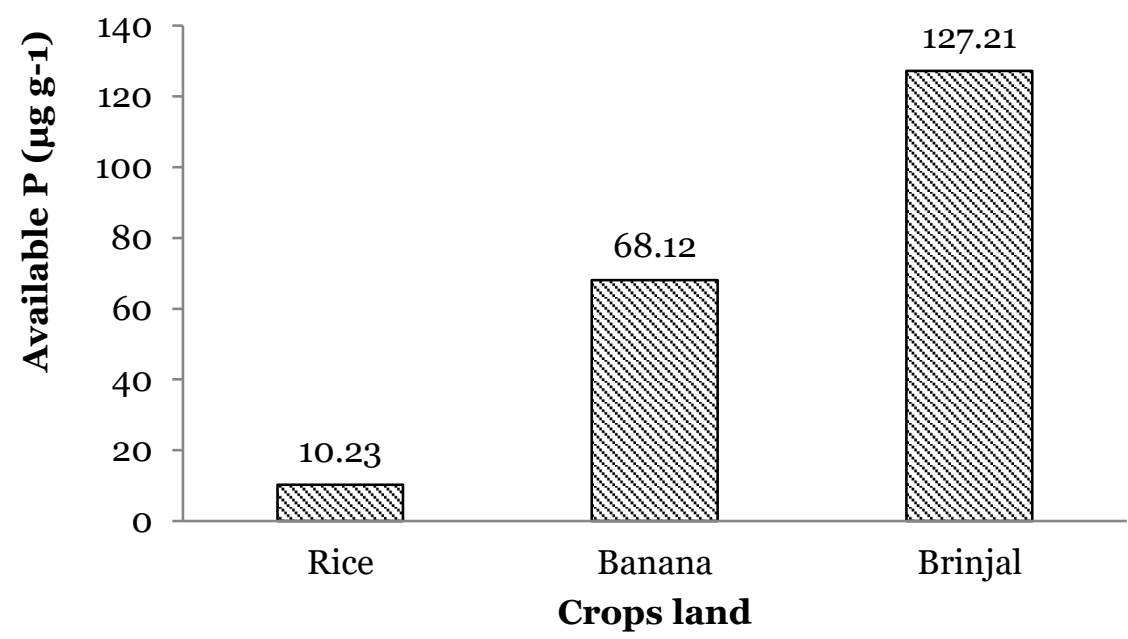

Fig. 5. Available phosphorus status of different crops growing lands.

\section{Available zinc (Zn)}

Brinjal growing land showed significantly highest

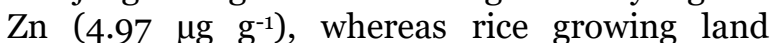
showed lowest (0.84 $\left.\mu \mathrm{g} \mathrm{g}^{-1}\right)$ and brinjal growing land was almost similar with banana $\left(3.79 \mu \mathrm{g} \mathrm{g}^{-1}\right)$ growing land (Fig. 6). The optimum level of $\mathrm{Zn}$ is 1.35 to $1.80 \mu \mathrm{g} \mathrm{g}^{-1}$ for all the agricultural crop production (Ahmed et al., 2018). Available Zn level of banana and brinjal growing land were very high, whereas it was low in rice growing land (Table 1). Available $\mathrm{Zn}$ content of rice growing land was not suitable but banana and brinjal growing land were suitable. According to Islam et al. (2020b), available $\mathrm{Zn}$ ranged from 0.94 to $6.35 \mu \mathrm{g} \mathrm{g}^{-1}$ with a mean of $3.25 \mu \mathrm{g} \mathrm{g}^{-1}$, which was above the optimum (very high) range and considered more than adequate for crop production. Available $\mathrm{Zn}$ was higher in high land (1.56 $\left.\mu \mathrm{g} \mathrm{g}^{-1}\right)$ than medium high land $\left(1.49 \mu \mathrm{g} \mathrm{g}^{-1}\right)$ and medium low land $\left(0.96 \mu \mathrm{g} \mathrm{g}^{-1}\right)$ in Tangail district (Kumar et al., 2019). 


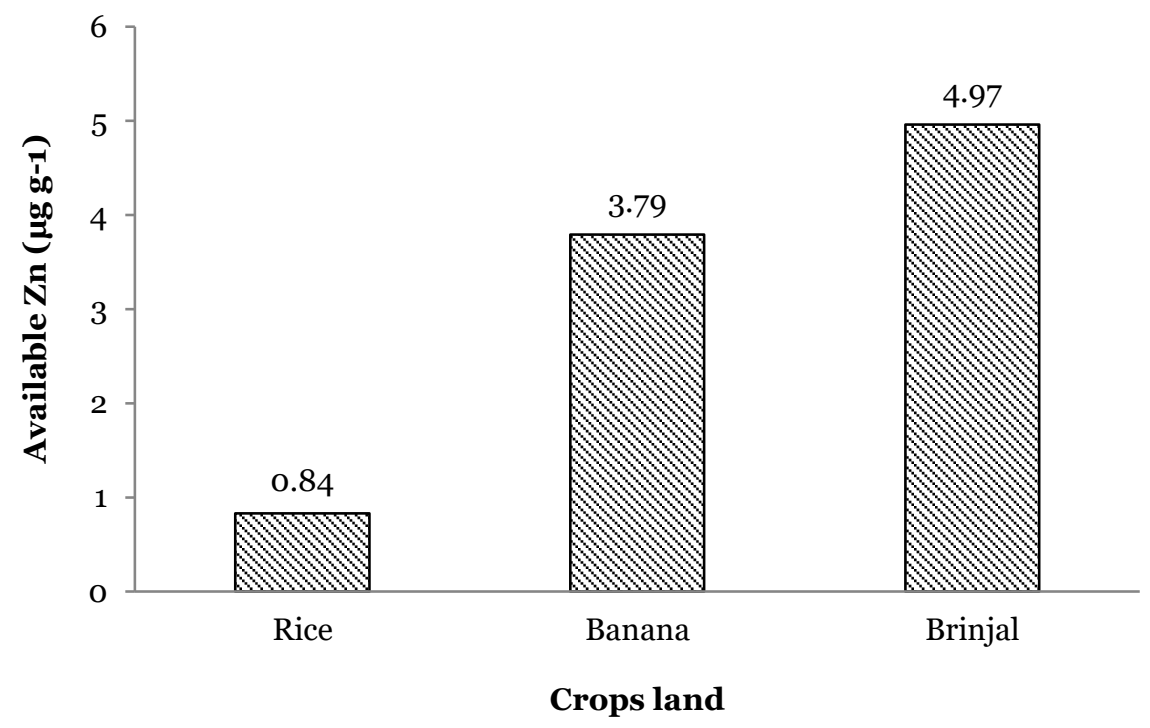

Fig. 6. Available zinc status of different crops growing lands.

\section{Available sulfur (S)}

Rice growing land showed highest available $\mathrm{S}$ $\left(35.53 \mu \mathrm{g} \mathrm{g}^{-1}\right)$ which was statistically similar with brinjal (32.78 $\left.\mu \mathrm{g} \mathrm{g}^{-1}\right)$ growing land, whereas banana growing land showed the lowest $(30.23$ 21.00 $\mu \mathrm{g} \mathrm{g}^{-1}$ ) (Fig. 7). The optimum level of

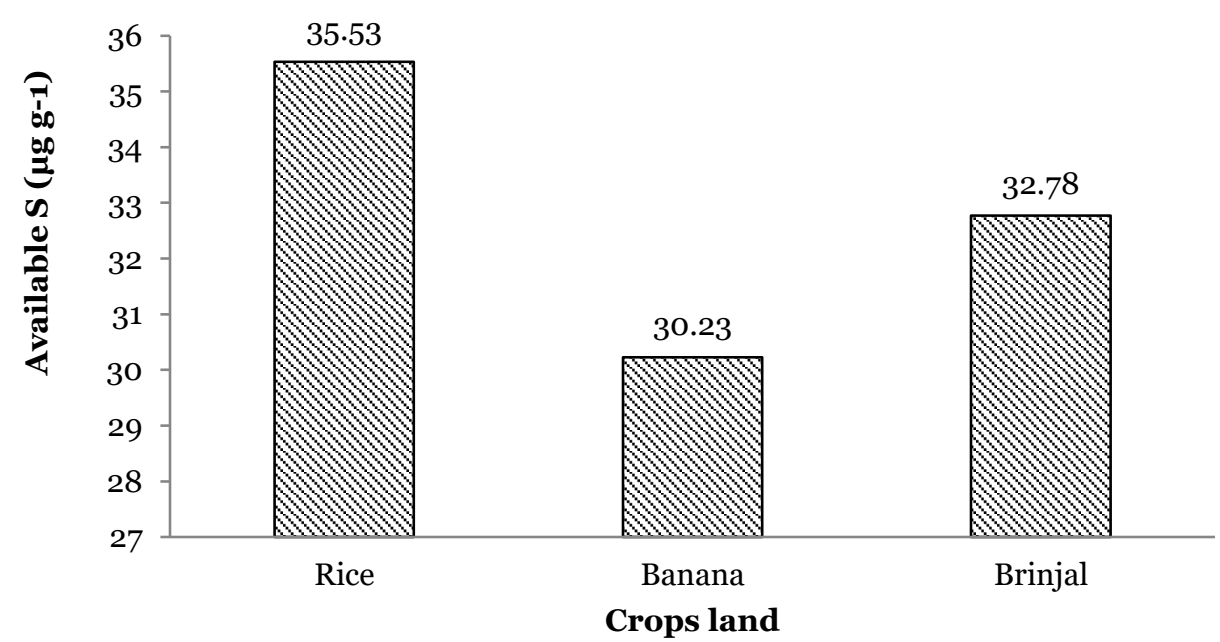

Fig. 7. Available sulfur status of different crops growing lands.

\section{Exchangeable potassium (K)}

Brinjal growing land showed significantly highest $\mathrm{K}\left(0.38 \mathrm{meq} 1 \mathrm{oog}^{-1}\right)$ where rice growing land showed lowest (0.14 meq $10^{\circ o g^{-1}}$ ) exchangeable potassium (Fig. 8). The optimum $\mathrm{K}$ is 0.27 to $0.36 \mathrm{meq} 1 \mathrm{oog}^{-1}$ for all the agricultural crop production (Ahmed et al., 2018). Potassium level of brinjal growing land was high whereas it was low and optimum in rice and banana growing land, respectively (Table 1). Potassium status of rice growing land is not suitable but banana and available $\mathrm{S}$ is 22.51 to $30.00 \mu \mathrm{g} \mathrm{g}^{-1}$ for all the agricultural crop production (Ahmed et al., 2018). Available $\mathrm{S}$ level of rice, banana and brinjal growing land were high which is suitable for crop production. brinjal growing land is suitable for crop production. This might be due to excessive use of $\mathrm{K}$ containing fertilizer in these two crops land. According to Islam et al. (2020b), the mean exchangeable $\mathrm{K}$ level was low (0.19 meq $100 \mathrm{~g}^{-1}$ ) in Kalihati upazila of Tangail. This study is well agreed with another study where they found that the exchangeable $\mathrm{K}$ was higher in high land (0.21 meq $10^{-1}$ ) than medium low land (0.19 meq $\left.100 \mathrm{~g}^{-1}\right)$ and medium high land (o.19 meq $\left.100 \mathrm{~g}^{-1}\right)$ in Tangail district (Kumar et al., 2019). 


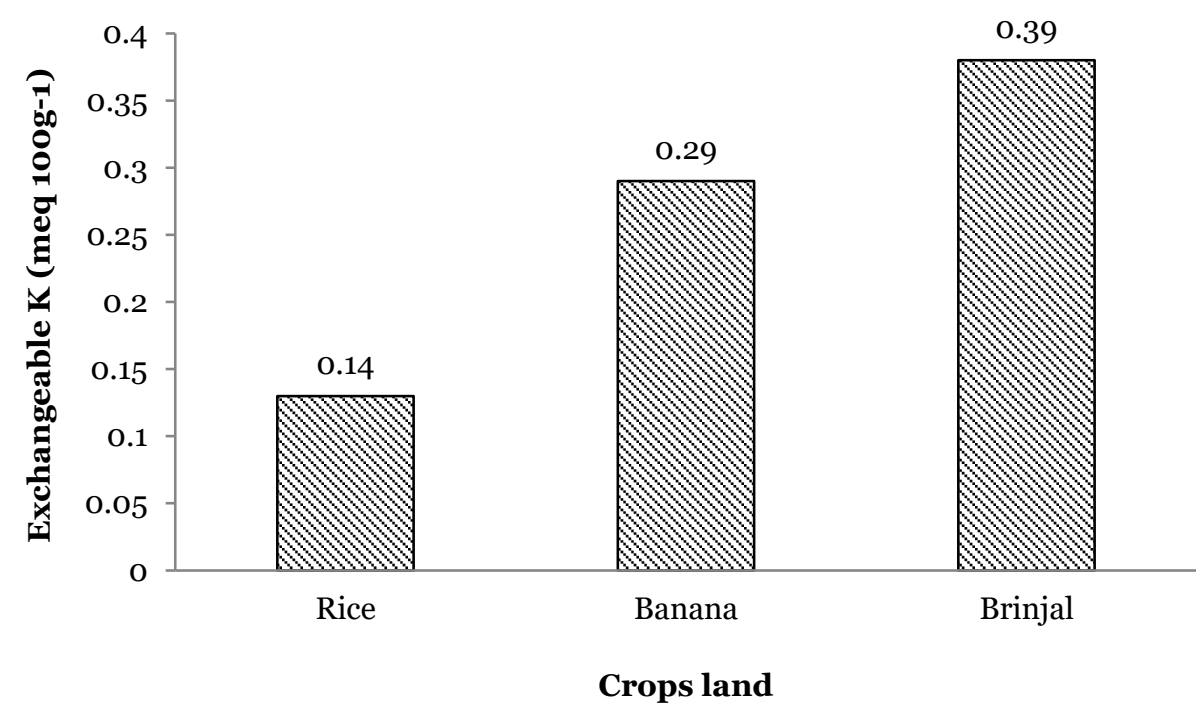

Fig. 8. Exchangeable potassium status of different crops growing lands.

\section{Exchangeable calcium (Ca)}

Rice growing land showed significantly highest $\mathrm{Ca}$ value (9.04 meq $1 \mathrm{OOg}^{-1}$ ) whereas banana growing land showed lowest (4.88 meq $\left.100 \mathrm{~g}^{-1}\right)$ and this was statistically similar with brinjal growing land (Fig. 9). Exchangeable Ca content of rice, banana and brinjal growing land were very high, optimum and high (Table 1) which is suitable for crop production. In other study of the mean Ca content was found optimum $(5.72 \mathrm{meq}$ $\left.10 \mathrm{~g}^{-1}\right)$ in all types of lands in Kalihati upazila (Islam et al., 2020b). Kumar et al. (2019) reported that exchangeable Ca was lower in high land (4.56 meq $\left.10^{-1}\right)$ than medium low land $\left(5.23 \mathrm{meq} 1 \mathrm{oog}^{-1}\right)$ in Tangail district, which supports the present study.

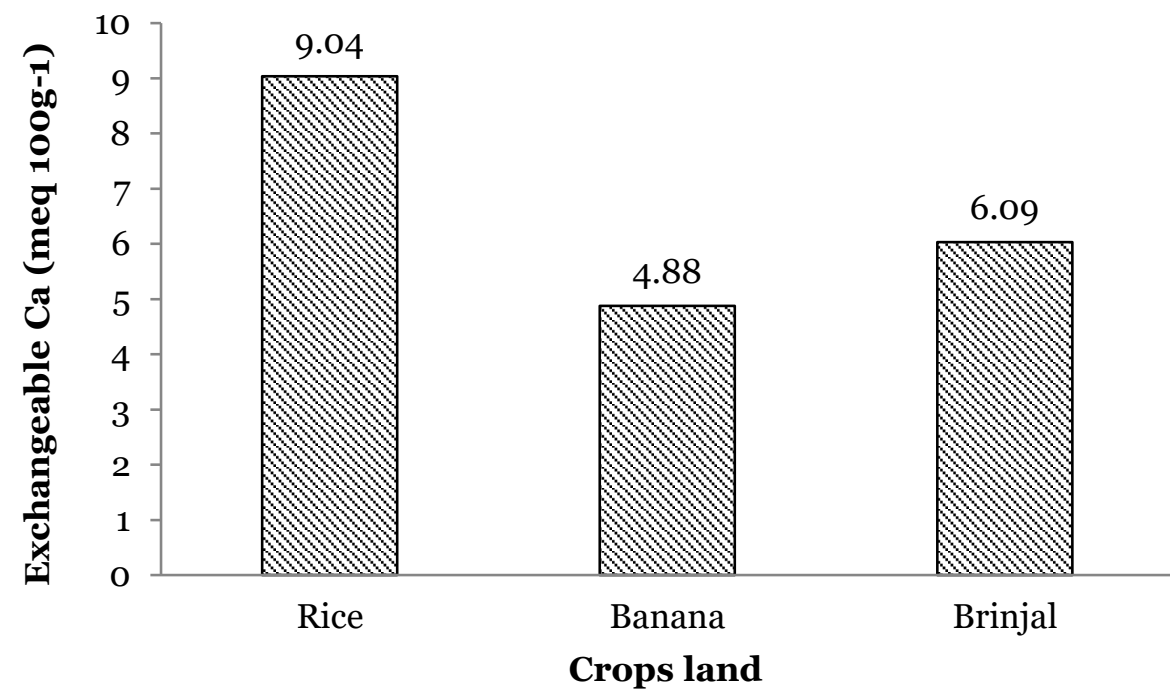

Fig. 9. Exchangeable calcium status of different crops growing lands.

\section{Exchangeable magnesium (Mg)}

Rice growing land showed significantly highest Mg (2.04 meq $\left.1 \mathrm{Oog}^{-1}\right)$ whereas banana growing land showed lowest $\left(0.77\right.$ meq $\left.100 \mathrm{~g}^{-1}\right)$ and this was similar with brinjal growing land (Fig. 10). Exchangeable Mg status of banana and brinjal growing land were medium but rice growing land was very high which is suitable for crop production (Table 1). According to Islam et al. (2020b), the mean Mg (2.07 meq $10^{-1}$ ) was found very high in Kalihati upazila of Tangail. Kumar et al. (2019) found that exchangeable Mg was lower in high land (1.31 meq $\left.100 \mathrm{~g}^{-1}\right)$ than medium low land (1.37 meq $\left.1 \log ^{-1}\right)$ in Tangail district. 


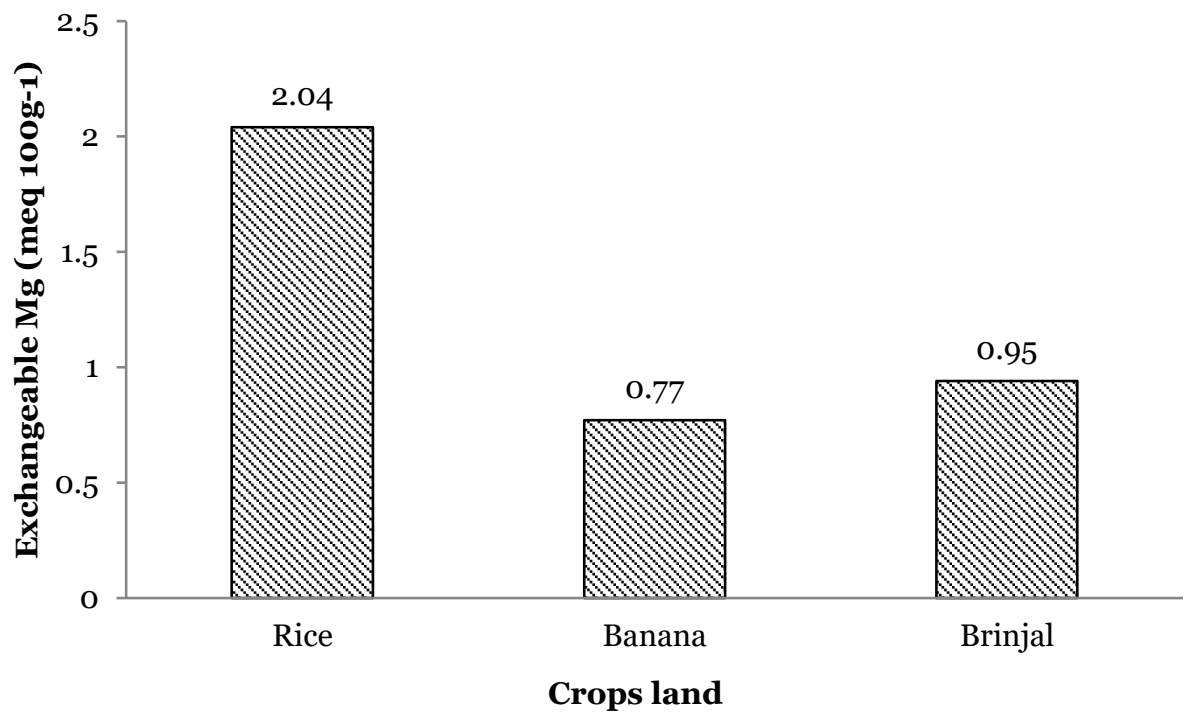

Fig. 10. Exchangeable magnesium status of different crops growing lands.

\section{Pesticide intensity}

Application of pesticide frequency was different in different land use pattern in the study area. The highest pesticide application frequency (4 times per crop) was found in brinjal and the lowest was found in rice ( 2 times per crop) and it was about three times per crop in banana production (Fig. 11). According to Sabur and Molla (2001), more pesticides are applied for all crops like potato, brinjal followed by rice and comparatively less pesticides used for banana (sagar) and mango production.

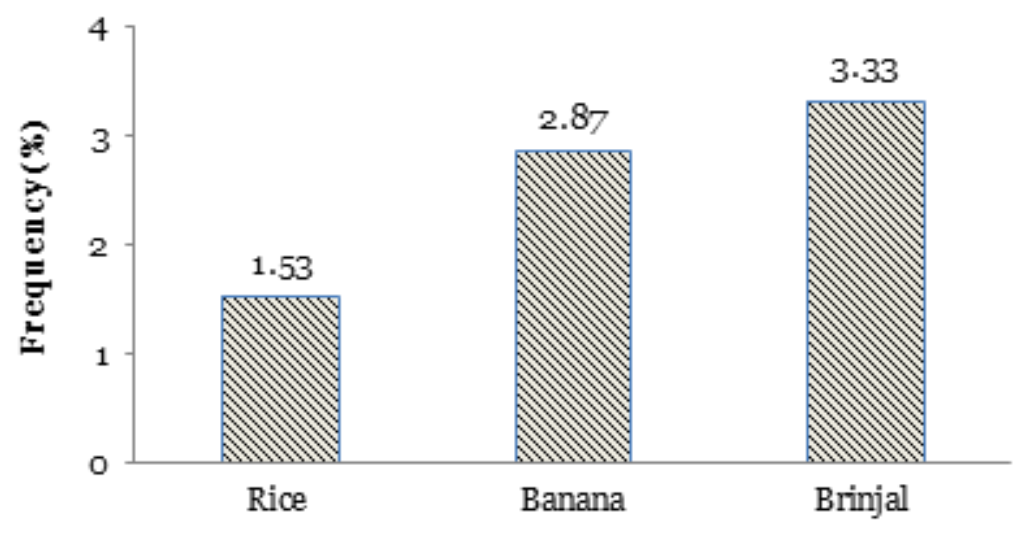

Fig. 11. Pesticide use intensity in different crops (rice, banana and brinjal).

Table 2. Correlations among the soil properties of different crops growing lands.

\begin{tabular}{|c|c|c|c|c|c|c|c|c|c|}
\hline & $\mathrm{pH}$ & $\mathrm{OM}$ & $\mathrm{N}$ & $\mathrm{P}$ & K & S & $\mathrm{Zn}$ & $\mathrm{Mg}$ & $\mathrm{Ca}$ \\
\hline $\mathrm{pH}$ & 1 & & & & & & & & \\
\hline $\mathrm{OM}$ & $0.37^{*}$ & 1 & & & & & & & \\
\hline $\mathrm{N}$ & $0.39^{* *}$ & $0.99^{* * *}$ & 1 & & & & & & \\
\hline $\mathrm{P}$ & $-0.05 n s$ & -0.20ns & $-0.18 n s$ & 1 & & & & & \\
\hline K & $-0.05 \mathrm{~ns}$ & $0.005^{n s}$ & $-0.03 n s$ & $0.55^{* * *}$ & 1 & & & & \\
\hline $\mathrm{S}$ & -0.03ns & $0.31^{*}$ & $0.31^{*}$ & $-0.05 \mathrm{~ns}$ & $0.07 \mathrm{~ns}$ & 1 & & & \\
\hline $\mathrm{Zn}$ & 0.05ns & $-0.12 n s$ & -0.11ns & $0.74^{* * *}$ & $0.45^{* *}$ & $-0.14 n s$ & 1 & & \\
\hline $\mathrm{Mg}$ & $0.54^{* * *}$ & $0.59^{* * *}$ & $0.60^{* * * *}$ & $-0.53^{* * *}$ & $-0.37^{*}$ & $0.17 \mathrm{~ns}$ & $-0.45^{* *}$ & 1 & \\
\hline $\mathrm{Ca}$ & $0.72^{* * *}$ & $0.63^{* * *}$ & $0.63^{* * *}$ & $-0.32^{*}$ & $-0.21 n s$ & $0.06 \mathrm{~ns}$ & $-0.27 \mathrm{~ns}$ & $0.87^{* * *}$ & 1 \\
\hline & & & $0.05,{ }^{* *} \mathrm{~F}$ & $.01, * * *$ & $0.001, \mathrm{~ns}$ & on- si & & & \\
\hline
\end{tabular}

Note: OM= Organic matter, $N=$ Available $N, P=$ Available $P, K=$ Exchangeable $K, S=$ Available $S, Z n=$ Available $\mathrm{Zn}, \mathrm{Mg}=$ Exchangeable $\mathrm{Mg}, \mathrm{Ca}=$ Exchangeable Ca. 
Organic matter, available $\mathrm{N}$, exchangeable $\mathrm{Mg}$ and exchangeable $\mathrm{Ca}$ showed a significant positive correlation $(r=0.37,0.39,0.54,0.72)$ with $\mathrm{pH}$. Available $\mathrm{N}$, available $\mathrm{S}$, exchangeable $\mathrm{Mg}$ and exchangeable $\mathrm{Ca}$ showed a significant positive correlation $(\mathrm{r}=0.99,0.31,0.59,0.63)$ with OM. Available S, exchangeable $\mathrm{Mg}$ and exchangeable $\mathrm{Ca}$ showed a significant positive correlation $(\mathrm{r}=0.31,0.60,0.63)$ with available $\mathrm{N}$. Exchangeable $\mathrm{P}$ and available $\mathrm{Zn}$ showed a significant positive correlation $(\mathrm{r}=0.55,0.74)$ with available $\mathrm{P}$, but a significant negative correlation with exchangeable $\mathrm{Mg}$ and exchangeable $\mathrm{Ca}(\mathrm{r}=-0.53,-0.32)$. Available $\mathrm{Zn}$ showed a significant positive correlation $(\mathrm{r}=0.45)$ with exchangeable K. Exchangeable Ca showed a significant positive correlation $(\mathrm{r}=0.87, \mathrm{P} \leq 0.001)$ with exchangeable Mg (Table 2).

\section{Conclusions}

The $\mathrm{pH}$ of rice and brinjal growing land was slightly acidic, and OM levels were medium, which was suitable for cultivation, but it was low in banana growing land, which posed a threat to banana production. Available N status of banana and brinjal growing land were very low whereas it was low in rice growing land, which was lower than optimum level that means more fertilizer will be required for agricultural crop production. Available P status of banana and brinjal growing land were very high that is suitable for banana and brinjal cultivation whereas it was low in rice growing land that is not suitable for rice cultivation. Exchangeable $\mathrm{K}$ status of brinjal growing land was high whereas it was low and optimum in rice and banana growing land. Available S status of rice, banana and brinjal growing land were high which is suitable for crop production. Available Zn status of banana and brinjal growing land were very high whereas it was low in rice growing land. Exchangeable $\mathrm{Ca}$ status of rice, banana and brinjal growing land were very high, optimum and high which is suitable for crop production. Exchangeable $\mathrm{Mg}$ status of banana and brinjal growing land were medium but rice growing land was very high which is suitable for crop production. The highest pesticides were applied in brinjal and lower in rice. To minimize loss of soil nutrients and degradation of soil quality by using excessive use of pesticide, some recommendations can be raised as making farmers awareness about soil fertility and adverse effect of pesticides and ensure soil health suitable eco-friendly policy should be taken.

\section{Acknowledgements}

Sincere gratitude to the staffs of the Soil Resource Development Institute (Tangail) for their technical support during the analysis of soil samples in the laboratory.

\section{References}

Ahmed, S., Jahiruddin, M., Razia, M.S., Begum, R.A., Biswas, J.C., Rahman, A.S.M.M., Ali, M.M., Islam, K.M.S., Hossain, M.M., Gani, M.N., Hossain, G.M.A. and Satter, M.A. 2018. Fertilizer Recommendation Guide-2018. Bangladesh Agricultural Research Council (BARC), Farmgate, Dhaka 1215, Bangladesh. p. 223.

Akhter, M.N., Chakraborty, T.K., Ghosh, P., Jahan, S., Gosh, G.C. and Hossain, S.A. 2016. Assessment of the using patterns of pesticides and its impact on farmers health in the Jhenidah district of Bangladesh. American J. Environ. Protec. 5(5): 139-144. https://doi.org/10.11648/j.ajep.20160505.16

BBS (Bangladesh Bureau of Statistics). 2018. Statistical Yearbook of Bangladesh, Bangladesh Bureau of Statistics, Planning Division, Ministry of Planning, Government of the People's Republic of Bangladesh, Dhaka. P. 126.

Conway, G.R. 1984. Strategic models. In: G.R. Conway (Ed.), Pest and Pathogen Control: Strategic, Tactical and Policy Models. International Series on Applied Systems Analysis, John Wiley \& Sons, pp. 5-10.

Cycon, M. and Piotrowska-Seget, Z. 2007. Effect of selected pesticides on soil micro-flora involved in organic matter and nitrogen transformations: pot experiment. Polish $J$. Ecol. 55(2): 207-220.

Hart, J.M., Sullivan, D.M., Anderson, N.P., Hulting, A.G., Horneck, D.A. and Christensen, N.W. 2013. Soil acidity in Oregon: understanding and using concepts for crop production. EM 9061, OSU Extension, Corvallis, OR, USA. p. 22.

Huq, S.M.I and Alam, M.D. 2005. A handbook on analysis of soil, plant and water. Bangladesh Australia Centre for Environmental Research (BACER-DU), Dhaka, pp. 61-117.

Imfeld, G. and Vuilleumier, S. 2012. Measuring the effects of pesticides on bacterial communities in soil: a critical review. European J. Soil Biol. 49: 22-30. https://doi.org/10.1016/j.ejsobi.2011.11.010

Islam, M.S., Jamil, M.R., Chowdhury, M.N., Kabir, M.H. and Rimi, R.H. 2020a. Impact of cyclone and flood on crop and fish production in disaster prone coastal Bhola district of Bangladesh. Int. J. Agril. Res. Innov. Tech. 10(1): 40-55. https://doi.org/10.3329/ijarit.v10i1.48093

Islam, M.S., Nusrat, T., Jamil, M.R., Yesmin, F., Kabir, M.H. and Rimi, R.H. 2020b. Investigation of soil properties and nutrients in agricultural practiced land in Tangail, Bangladesh. Int. J. Agril. Res. Innov. Tech. 10(2): 84-90.

https://doi.org/10.3329/ijarit.v10i2.51581 
Kumar, U., Rashid, H., Tithi, N.H. and Mia, M.Y. 2019. Status of soil properties in relationship with soil $\mathrm{pH}$ in Madhupur tract of Tangail district in Bangladesh. Prog. Agric. 30(3): 282-287. https://doi.org/10.3329/pa.v3oi3.45153

Liu, C.J., Men, W.J., Liu, Y.J. and Zhang, H. 2002. The pollution of pesticides in soils and its bioremediation. Syst. Sci. Compre. Stud. Agric. 18(4): 295-297.

Meisner, C. 2004. Report of pesticide hotspots in Bangladesh, report to the Canadian International Development Agency, Mimeo, World Bank: Washington DC, pp. 1-18. Available at: http://www.worldbank/nipr

Nazif, W., Perveen, S. and Saleem, I. 2006. Status of micronutrients in soils of district Bhimber (Azad Jammu and Kashmir). J. Agril. Biol. Sci. 1(2): 35-40.

PAB (Pesticide Association of Bangladesh). 2000. Pesticides consumption report for the year 1999/2000. Pesticide Association of Bangladesh, Dhaka, pp.18-19.

Parveen, S. and Nakagoshi, N. 2001. An analysis of pesticide use for rice pest management in Bangladesh. J. Int. Dev. Cooper. 8(1): 107126.
Prasad, N.V.V.S.D., Chenga reddy, V. and Narayana, E. 2014. Impact of pesticide used for crop production on the environments. In: National seminar on impact of toxic metals, minerals and solvents leading to environmental pollution-2014. J. Chem. Pharma. Sci. 3(Special issue): 75-79.

Roberts, S., Vodraska, R.V., Kauffman, M.D. and Gardner, E.H. 1971. Methods of soil analysis used in the soil testing laboratory at Oregon State University (Special Report), USA, $321 \mathrm{p}$.

Sabur, S.A. and Molla, A.R. 2001. Pesticide use, its impact on crop production and evaluation of IPM technologies in Bangladesh. Bangladesh J. Agril. Econ. 24: 21-38.

Sattar, D.M.A. and Rahman, M.M. 1987. Techniques of soil analysis. Department of Soil Science, Bangladesh Agricultural University, Mymensingh. pp. 67-124. 